tional resources. The conflicts will also thwart the proposals to create a more differentiated, California-like system. Needless to say, charging tuition for high-income students in public universities will not be raised. This issue is forbidden in the Brazilian constitution. No politician in Brazil has dared to publicly defend this policy, while many do agree in private, because of the inevitable backlash from radical students and unions.

\section{Recent Changes in Venezuelan Higher Education}

\section{OrLAndo Albornoz}

Orlando Albornoz is a professor at the Universidad Central de Venezuela. Apartado postal no. 50.061, Caracas 1050-A, Venezuela. E-mail: oalborno@reacciun.ve.

Few countries in Latin America and the Caribbean have experienced as many drastic changes in higher education as have taken place in Venezuela's system. In less than a decade this system has moved away from the format of the conventional system common throughout the region to a political and ideological approach raising many questions about the academic standards that are supposed to be at the core of the mission of higher education.

\section{POLITICS AND IDEOLOGY}

Venezuela is undergoing an accelerated transformation in the political and ideological arena, driving the changes in the country's higher education system. Between I958 and I998 this society worked under the standard framework of a democratic process. The key concepts of the system-modernization and development-promoted the growth of a highly successful diversified and pluralistic higher education system that trained the professionals needed by society as well as the ruling political elite. But the system failed in two critical aspects: meeting the growing demand for access to higher education and stopping the malaise caused by administrative and academic corruption so deeply embedded in the system that it still prevails today.

The I998 elections brought a new government into office. Instead of business as usual, a revolutionary vision came into power, and the society began the transition from capitalism to socialism, from democracy to autocracy.

\section{Changes in Higher Education}

The four stages in the Venezuelan case have transformed this system in less than a decade. This article analyzes these changes and establishes the prospect for the future of this system. The earlier conventional Venezuelan higher education constituted a typical Latin American system. Both the state and the private sector served as key actors among institutions. Links existed to Europe and the United States. The middle and upper classes held an advantage in terms of access. Standards tended to pass along a continuum with low and high extremes of academic quality, with educational technology oriented toward teaching more than research.

In 2002, the new government came into power and promised to respond to popular needs in higher education, and that meant providing access, which was almost closed to the poor and general public of society. This goal was reached, with access opened no matter what the cost of diminishing academic quality. The trade-off on these matters is rather difficult to solve, given the improbability of combining universal access and increased academic quality.

The government's first higher educational initiative included opening the Universidad Bolivariana de Venezuela and expanding the Universidad Nacional Experimental de la Fuerza Armada. At the same time they created alternative programs - such as the misiones (missions) educational programs designed to enhance the training of students willing to enter higher education, as well as the aldeas universitarias (university villages) to reach rural areas lacking higher education. These programs were subsidized by the government through modest but highly popular scholarship programs, increasing the political support for the government.

The third stage of this higher education policymaking consists of the motores - the engines of the rapid changes that are transforming this society in ideological terms. Ideologization

Venezuela is undergoing an accelerated transformation in the political and ideological arena, driving the changes in the country's higher education system.

is now the key element of the system. In keeping with the political landscape, the president's brother has been in charge of this development as minister of education and after three years as ambassador to Havana.

The final stage is the internationalization of the system, creating in Venezuela universities that are Latin American. Thus, instead of the national standard system, the country is preparing to train people from all over the region according to its ideological and revolutionary vision, an approach first begun in Cuba in the late ig6os and now being transferred to Venezuela.

\section{Contradictions and Conflicts}

These actions have not avoided opposition and conflicts. The vice rectors for academic affairs of all Venezuelan universities 
declared in April 2007 that the country has suffered a "profound fracture in its political organization." Of the two rectors' associations, AVERU (Asociación Venezolana de Rectores Universitarios) covers the autonomous and private-sector universities and ARBOL (Asociación de Rectores Bolivarianos) represents the rectors of the government-controlled institutions.

The conflicts arise from the government's tense relationship with autonomous universities and the strong private sector. These institutions face ongoing threats by a government whose public policies focus on absolute control of institutions in this rich petro state and poor society-ranging from the Parliament to the Supreme Court, the Army, and the employees of the public administration. The government is also trying to control the mass media and private services in most areas including the area of health care. If the logic of the revolutionary government prevails sooner or later the whole higher educational system will fall under government control.

Surprisingly enough, this policy is being carried out with special care to work under legal procedures. No universities have been closed down, no students persecuted, and no

The third stage of this higher education policymaking consists of the motores - the engines of the rapid changes that are transforming this society in ideological terms. Ideologization is now the key element of the system.

professors jailed because of their political views. Little by little, however, under the slogan of the revolution ("fatherland, socialism or death") the political opposition and is being eliminated. This society is being confronted with the predicament of a single line of thought dominating public discourse and a sole leader who is omnipresent in Venezuelan daily life all over the country.

However, these contradictions and conflicts remain profound since many people in society object to absolute power held by a small group led by the military. While the final outcome is largely unforeseeable at this stage, it will be interesting to see what finally happens to higher education in Venezuelathat is, coming under the total control of the government or managing to sustain some institutional autonomy and academic freedom. At the end of the day, transforming higher education without a vision for learning in the 2Ist century does not help academic quality and with it modernization and development. Thus how to erase inequality and to improve academic quality is still the challenge for countries like Venezuela.

\section{Syrian Higher Education: Responding to a Changing Economy}

\author{
David Hardy and Roger Munns
}

David Hardy is director of Distance Education International and past president of the European Association of Distance Teaching Universities. Address: The Farmhouse, Lycrome Road, Lye Green, Chesham, Bucks HP5 3LD, UK. E-mail: d.hardy@mailbox.ulcc.ac.uk. Roger Munns is senior education adviser at the British Council. Address: 10 Spring Gardens, London SW1A 2BN, UK. E-mail: roger.munns@britishcouncil.org.

$T$ he economy of the Syrian Arab Republic is heavily reliant on oil and agriculture. Under the leadership of President Bashar Al-Assad, the government is seeking to diversify the economic base, putting in place a social market economy with a vibrant business sector. To achieve these aims a reformed higher education sector is seen as a priority by the president. He wishes to see high-quality, relevant education geared to the needs of business and the economy.

\section{THE BACKGRound}

For the past 20 years there have been 4 state-funded universities in Damascus, Aleppo, Homs, and Tishrin. A 5th has just been set up in Deirezzor. There are also I92 intermediate institutes under the Vocational Education and Training Directorate of the Ministry of Higher Education. Of these, 34 are under the direct control of the Ministry of Higher Education, the rest are controlled by i7 different ministries.

The current education policy gives all school leavers who pass the baccalaureate exam the opportunity to go into higher education. Out of II4,298 school leavers who passed in 2006, 98,7I8 continued into higher education-universities or Higher Education Institutes-which is about 22 percent of all school leavers. In 2005/06 there were 244,292 undergraduate and $\mathrm{I} 2,384$ postgraduate students at state universities.

Popular information technology courses at the University of Damascus have a student/staff ratio of Ioo/I. Humanities courses have so many students that self-study is the norm, with maybe Io percent of students attending lectures. Assessment is hugely difficult given the numbers. The use of multiple-choice essay questions emphasizes the difficultythat is, there is not enough time to mark student essays. Students are allocated to subjects according to their baccalaureate marks rather than demand. Teaching is often of poor quality. A whole generation of teachers were instructed in the former Soviet Union and have hardly been updated since. The education process is driven by political and not market needs. Its origins lie in the I970s and the late President Assad's 